\title{
4. Cultures of governance and the governance of culture: transforming and containing Indigenous institutions in West Arnhem Land
}

\section{Diane Smith}

You can't make people good by Act of Parliament.

(Oscar Wilde, A Woman of No Importance, Act 1)

We've had all our meetings and we had to be professional. We had to do our governance properly. We had all that governance training - now we're good! But the government people who pushed that 'good governance' idea; they aren't here. Where are they? They want us to govern, then they should let us govern.

(West Arnhem Shire Transitional Committee member)

\section{Introduction}

In the 40 years since the 1967 referendum $^{1}$ in Australia, governments have developed legislation, policies, and a multitude of institutional mechanisms in their attempts to govern the Indigenous population and address its entrenched socioeconomic disadvantage. These interventions into Indigenous lives by the state have been primarily predicated on western values, institutions and beliefs about what constitutes 'good governance' and, accordingly, what Indigenous Australians should do to develop it.

Implicit in these government strategies has been a deep-seated lack of confidence in Indigenous 'culture' itself, exacerbated by contradictory underlying assumptions. On the one hand, the hope of policy makers is that if they can only unlock the 'da Vinci Code' of Indigenous culture they will somehow be able to design more 'culturally appropriate' government programs and service delivery, thereby more effectively securing government policy objectives. On the other hand, Indigenous culture is often pathologised by politicians, bureaucrats, the public, and the media. It is viewed as a form of inherited virus that will inevitably contaminate and undermine western standards of 'good governance'. So, 'Acts

\footnotetext{
1 The 1967 referendum made two changes to the Australian Constitution. These changes enabled the Commonwealth Government to make laws for all of the Australian people by amending s. 51 of the Constitution (previously, people of 'the Aboriginal race in any State' were excluded); and to take account of Aboriginal people in determining the population of Australia by repealing s. 127 of the Constitution (formerly, Indigenous people had been haphazardly included in the census, but not counted for the purposes of Commonwealth funding grants to the states or territories).
} 
of Parliament' and the often unilateral imposition of the state's sovereign powers are deemed to be necessary to 'protect' Indigenous people from the governance disabilities of their own culture. At such times, the Australian state reasserts its own 'culture of governance' - that is, the set of shared values, government institutions, powers, laws, modes of behaviour and norms - in an attempt to direct and mould Indigenous cultures and their systems of governance into its own democratic likeness.

This chapter poses two symbiotic concepts - the 'governance of culture' and 'cultures of governance' - as tools to analyse the nature of the tangled engagement between contemporary Indigenous and non-Indigenous 'cultures of governance' in Australia. Points of interaction focus on the institutional and practice level of governments, and Indigenous communities, their leaders and organisations.

Institutions are the glue of governance; they are the 'rules of the game', the formal and informal ways in which things get done. As such, institutions are pre-eminently about power and who gets to exercise it. In the intercultural context of post-colonial governance in Australia, institutions represent a rich site of visible interaction and contestation between the Australian state and Indigenous peoples.

Employing these two concepts, this chapter first examines how the Australian state attempts, through its policy, statutory and bureaucratic institutions, to govern contemporary Indigenous cultures and their different systems of governance. The same concepts are then used to explore the ways in which Indigenous people use their culturally-based institutions to buffer and reassert the legitimacy of their governance arrangements and decision-making authority. In doing so, Indigenous governance institutions are being re-imagined, recreated, transformed and constrained - both from within and without. But the institutions of the Australian state, in the arena of policy and implementation, are also being affected. Both sets of mutual transformation and containment are investigated.

The analysis focuses specifically on a case study conducted over the last five years in West Arnhem Land. There, Indigenous people (referred to as Bininj in the local Kunwinjku language) and the Northern Territory (NT) Government have been involved in planning the establishment of a regionalised form of local government, for the purposes of delivering essential municipal services and infrastructure to the region as a whole. Some of the Bininj leaders involved are relatives of families with whom I worked over 25 years ago when employed by the Northern Land Council to map land-tenure systems in West Arnhem Land.

In the course of working towards their goal of a strong regional organisation, several Bininj community organisations and their elected leaders have attempted to build elements of a new 'culture of governance'. To do so, they have used a range of techniques and tools to design innovative governance institutions and structures, and to imbue them with practical capability and legitimacy. 
In this chapter I examine the design techniques and their points of intersection with government processes, and consider the implications for both the Bininj and government parties. Not all the initiatives and solutions are seen as legitimate or effective by the state, or by some Indigenous community members. How the disjunctions between the two cultures of governance are contested and negotiated forms a large part of the analysis. Whether the process has led to the desired (and different) practical outcomes sought by the Indigenous and non-Indigenous (or Balanda in Kunwinjku language) participants involved, and whether there has been any growth in their mutual comprehension are considered by way of conclusion.

\section{The research process}

The research on which this paper draws is ethnographic, multi-sited, and aims to make both a practical and a policy contribution, and so deserves a brief account. Over a 25 year period I have undertaken sporadic field based research with Indigenous families and groups in West Arnhem Land on their traditional land tenure patterns and social organisation. This work has included mapping clan countries and sacred sites, assessing the socioeconomic impact of mining and other resource agreements, and reviewing the operation and performance of Indigenous organisations. An integral part of the research has been analyses of the wider government policy, legal and funding environment within which Indigenous rights, interests and institutions have been recognised or limited.

My research frequently ventured into the cultures of government bureaucracy and departments. Most recently, between 2003 and 2006, I was engaged as a part-time policy researcher by the NT Government's Department of Community Development, Sport and Cultural Affairs (DCDSCA) under contract with my employer, the Centre for Aboriginal Economic Policy Research (CAEPR) at The Australian National University. During that period, I provided research analysis, evaluation and advice to the Department regarding the effectiveness of government policy, projects and implementation regarding Indigenous governance, community development and regionalisation.

In 2004, I was invited by two of the department's Community Development Officers (CDOs) to work with them on planning and implementation for a specific regional local government initiative in West Arnhem Land. Shortly after, I was asked by the Indigenous members of the newly-formed West Arnhem Land Regional Authority (WCARA) Interim Council representing the communities and organisations involved, to continue this work with them and attend their meetings. This, in turn, further engaged me in departmental (as well as inter-agency and cross-government) meetings about the local government reform over 2004-06. 
In late 2006, after my contract with the Department had finished and I returned to my university, the Interim Council requested that the WCARA process become part of the national Indigenous community governance research that I was jointly involved in conducting. Subsequently, I have continued to work in the capacity of researcher and 'special advisor' to the Indigenous members of this West Arnhem regional committee.

These overlapping professional roles enabled me to experience first hand the different government, bureaucratic, and Indigenous culturally-based perspectives, strategies and agency at play in the regional initiative. Whilst it was by no means inclusive of all the parties involved, and on occasions problematic, the multi-sited research generated an unusually broad set of insights into the complex and rapidly changing intercultural process.

\section{Seeing governance like a state}

Perhaps no people ever had more rudimentary rules of law and government than those savages ... with hardly any government over the wandering clan except the undefined authority of the 'bully' of the tribe.

(Tylor 1894:150)

... in many Aboriginal communities, social organisation has completely broken down. The people have shown they are incapable of governing themselves. There is no point in consulting them about the creation of authority; authority has to be created for them. Their lives will then better match our own.

(Hirst 2007)

How we see governance makes a difference. As the commentators above suggest, from colonial settlement through to today, Indigenous governance has often seemed invisible, unknowable, and underdeveloped to non-Indigenous Australians. It has been treated as a kind of 'gubernare nullius', ${ }^{2}$ a tabula rasa onto which could be written the language, norms and institutions of western liberal statecraft and control.

In Seeing Like a State, James Scott (1998: 3) argues that efforts to permanently settle highly mobile sub-populations like nomads, gypsies, vagrants, and

\footnotetext{
2 The word 'governance' is derived from the Latin word 'gubernare' meaning 'rudder', conveying 'the action of steering a ship'. The word was first used in 12th century France, where it was a technical term designating the administration of a bailliage (the jurisdiction or district of a bailiff; bailiwick in English). From France, it crossed the channel and in England came to designate the method of organising feudal power (see de Alcantara 1998; Kooiman 2003; and Plumptre and Graham 1999 for a definitional autobiography of the concept). Just as the British legal concept of terra nullius was used to usurp control over the lands of Indigenous Australians, the related idea that they had no government, no chiefs, and no enduring form of authority, law and order was used to justify the imposition of British jurisdiction and the common law over Indigenous lands and people.
} 
hunter-gatherers has been a perennial project of the modern state, underwritten by strategies to standardise and simplify 'what was a social hieroglyph into a legible and administratively more convenient format'. In Australia, British colonists similarly went to considerable lengths to make the alien social and institutional 'hieroglyph' of Indigenous governance and leadership legible to themselves.

In the early days of the colony, Indigenous groups were perceived to be acephalous, lawless and unruly. Metal 'kingplates' and 'queenplates' were bestowed on favoured elders - hung around their necks to make them visible to the British authorities. People were often forcibly relocated from their lands and centralised into artificial communities where 'councils of elders', 'chiefs', 'kings' and 'queens', 'princes' and 'headmen' were created by missionaries and government reserve managers as part of an arsenal of techniques to govern and immobilise people. This naming of Indigenous governance was about state surveillance and control.

Today, western democratic concepts, structures and governance institutions continue to be imposed through such devices as legislative and policy frameworks that require the incorporation of social groups into organisations; the ordering concepts of democratic elections and voting systems; the asserted primacy of individual citizenship over collective rights; and via the statutory naming of newly-created categories of people on whom are bestowed specified decision-making rights, responsibilities and authority by the state.

The allocated mark of condoned authority is still used by governments. There are now legal categories of people - such as 'traditional owners', 'authorised claimants' and 'native title holders' - who have to be registered and certified, and 'councillors', 'chairpersons', 'bodies corporate' and 'governing boards' who are required to operate under legal and constitutional guidelines. ${ }^{3}$

Government's own 'culture of governance' in Indigenous affairs is based on institutionalised forms of policy, program and grant funding that are supported by the tools of financial compliance and accountability, service delivery outcomes, administrative review, and technical audits. These tools are activated by the ever-changing face of government departments, agencies and committees, which work to defend their relative influence, functional 'territories' and budgetary power.

\footnotetext{
${ }^{3}$ This categorisation for the purposes of making Indigenous people visible and susceptible to external control is not restricted to governance. It is especially apparent in the history of the census enumeration by Australian governments, where people are renamed and so transformed into 'households', 'household reference person', 'nuclear families', 'visitors' etc. (see Morphy 2007). In resource negotiations with private sector companies, people are renamed and transformed into 'stakeholders', 'land owners', 'historical peoples', 'beneficiaries', 'affected groups' etc. (see Holcombe 2005; Howitt and Suchet 2004; Smith 1995). In the social security system they are renamed and reconstituted as 'sole parents', 'welfare dependents', and people 'in breach' (see Smith 1992).
} 
Aligned to departmental territories are vast bureaucratic networks where influential senior officers formulate policy frameworks and devise implementation strategies for government consideration. In doing so, they create their own internal language for the operation of Indigenous affairs. ${ }^{4}$

For most public servants, the face of Indigenous governance is incorporated community organisations, of which there are an estimated 5000 across Australia. Even in the most well-intentioned policy approaches, the governance of Indigenous organisations is invariably made subservient and overwhelmed by the workload of mundane bureaucratic procedures and financial reporting that they are required to undertake.

As public servants are increasingly centralised and work behind the key-coded locked doors of departmental offices, they become further distanced from the practical realities of Indigenous community governance. The overall effect has been a growing field-based disengagement of bureaucrats from Indigenous communities, and a widening misalignment between government policy and departmental practice.

For Indigenous communities and their organisations, the state does not exist 'up there', at a disembodied remove from them. The sovereign governing power of the state is plain for Indigenous people to see on a daily basis. They experience it in the form of visiting public servants, the ever-changing rules of service delivery and funding, the deluge of information gathering by governments, and the burdensome routine of meetings and consultations.

In the local interaction between the state and Indigenous people, there are mutual blind spots where government policy rationales and decision-making processes are just as opaque and confounding to Indigenous people, as Indigenous governance processes and institutions are to governments and their officers.

But amongst the spaces of mutual unintelligibility of each other's 'social hieroglyphs' (cf. Scott 1998), some individual government field officers do make the room to develop personal relationships of trust with leaders and organisations, and so are better able to negotiate with them, provide credible advice, and undertake community development work. Similarly, some Indigenous leaders and organisations look for room to build relationships with particular public servants and, through them negotiate the conditions under which they can better exercise their own authority, make decisions and mobilise action. They do so, however, in an environment of seemingly constant policy change and containment by the state. In the process they occasionally transform aspects of

\footnotetext{
4 In contemporary Indigenous Affairs, public servants have created powerful policy names such as 'coordination', 'whole-of-government', 'joined up government', 'mainstreaming', 'normalisation', 'transparency', 'mutual obligation, 'partnership' and so on.
} 
their own governance cultures, and subvert the techniques and institutions by which the state seeks to govern their culture and deny their self-governance.

This institutional interplay between 'cultures of governance' and the state's goal of 'governing Indigenous culture' is fully evident in the West Arnhem Land process of regionalising local government.

\section{The NT view of governance}

Northern Territory Government discussions with Indigenous leaders from West Arnhem Land about establishing a regional local government began in late 2002 under the reform agenda of the Building Stronger Regions, Stronger Futures (BSRSF) policy. Since then, the progress of the West Arnhem initiative has been subject to a constantly changing policy environment within the NT Government. The impacts of this have been exacerbated by equally tumultuous policy reforms at the national level.

\section{The collaborative phase}

The BSRSF policy was one in the long line of efforts by both the NT and Australian Governments to create various kinds of representative and administrative 'regions' over the Indigenous population. ${ }^{5}$ In the NT, its antecedents lay in the previous Government's policy initiative known as the Reform and Development Agenda (RADA). This policy sought to amalgamate the existing 65 local governing bodies ${ }^{6}$ into around 20 'larger and more sustainable' councils, 'ideally representing and delivering services to at least 2000 people'. A key goal of RADA was the creation of 'Indigenous governments with legitimate authority' (Coles 2004).

The BSRSF policy similarly sought the voluntary amalgamation of community councils into large-scale local governments, which were to be called Regional Authorities, with 20 expected to be established. The policy vision was to enact 'a radical transformation in the method of service delivery and regional Indigenous governance' (Ah Kit 2002; see also Ah Kit 2003: 2-3) in collaboration with community councils and their leaders.

The rationale was the perceived parlous state of local government councils in the Territory, characterised by one NT Minister as constituting a 'stark crisis' of governance that included widespread 'organisational bankruptcy',

\footnotetext{
${ }^{5}$ See Behrendt et al. (2007), Sanders $(2003,2004)$ and Smith $(1995,1996,2007)$ for a review of some of the different phases and forms of regionalism in Indigenous affairs.

6 These include six municipal councils, 31 community government councils that are incorporated under NT legislation, and 28 association councils that are constituted under Commonwealth legislation. Approximately 80 per cent of these councils are situated on Aboriginal inalienable freehold land and so must operate within the statutory context of the Aboriginal Land Rights (Northern Territory) Act 1976 (ALRA), which provides protection and recognition for the rights and interests of traditional owners in matters of land access, use, planning, and management.
} 
'institutional incapacity', 'ineffective service delivery, fraud and corruption by staff and leaders, a high turnover of key non-Indigenous staff', and an 'historical legacy of poor governance' (Ah Kit 2002: 1).

Evidence for that view came not only from lurid media accounts, but also from DCDSCA audits and compliance reviews of community councils. Those reported indicated that close to 50 per cent of local government bodies were either 'highly dysfunctional' or 'at risk' in terms of their financial management, service delivery and governance.

A critical factor underlying this failure rate has been the issue of scale. The average population serviced by Indigenous community and association councils is 670 persons (Local Government Association of the Northern Territory (LGANT) 2003: 4). In other words, many small, isolated community councils simply do not have the population size, economies of scale, resources, administrative systems, personnel or management expertise to adequately meet either their existing or potential service delivery obligations (Tapsell 2003).

In launching the BSRSF policy, the NT Government argued that 'effective and legitimate frameworks for regional governance [would be] the foundations for any regional development strategy that will be sustainable over time' (Ah Kit 2003). The policy intention was that regional authorities would:

- have jurisdiction and powers as regionalised forms of local government under the Local Government Act 1978 (NT)

- be established by 'voluntary agreement' between councils and require a 'substantial majority of residents in favour'

- be able to undertake 'regional decision making to determine priorities, establish service delivery policies and allocate resources', and

- 'provide for decision-making structures that meet the needs of the communities to be governed and, where applicable incorporate strong relationships with cultural decision-making arrangements and particularly traditional owners' (Ah Kit 2003).

The policy emphasis was to be on the flexibility of structures and timeframes, and the development of culturally-based representative and electoral arrangements.

A review of the Local Government Act 1978 (NT) was proposed to provide a better statutory foundation for regionalised local government. ${ }^{7}$

In mid 2004, at the end of the policy's first year of implementation, the Australian Government abolished the Aboriginal and Torres Strait Islander Commission

\footnotetext{
7 This review was never carried out. A new Local Government Bill was eventually introduced to the NT Legislative Assembly in February 2008; it was debated in the mid year sittings and enacted in the second half of 2008. The Bill implements the radically changed 'New Local Government' policy that was commenced in 2007, not the BSRSF policy launched in 2003.
} 
(ATSIC). ATSIC had been a statutory-based national forum for Indigenous Australians, based on the election of representatives from every state and territory. Its abolition, and the attendant dismantling of the regional council structure, left a major representative vacuum in the NT, as elsewhere. So, while one form of statutory regionalism was being abolished, the proposed regional local governments came to be seen as a possible alternative in the eyes of some in the NT and Australian Governments, and of some former ATSIC regional councillors as well.

To cement what became a fortuitous convergence of policy directions, support for regional authorities was included in a bilateral Overarching Agreement on Indigenous Affairs negotiated between the NT and Australian Governments in mid 2005. A schedule to the agreement set out shared goals for the two Governments, which included working together to ensure:

- 'effective and legitimate representation';

- that 'the establishment of Regional Authorities involves voluntary amalgamations of community councils based on extensive and effective consultation to ensure constitutions reflect local aspirations, and have cultural legitimacy'; and

- that the 'amalgamation of community councils into Regional Authorities effectively addresses current problems of scale, improves service delivery, reduces staff turnover and ensures greater coordination and continuity of interest in community economic and social development' (see Schedules 1 and 2.3 to the Overarching Bilateral Agreement on Indigenous Affairs, 2005). ${ }^{8}$

However, little more than 18 months later, in late 2006, the BSRSF policy framework was dramatically reformed by the NT Government and replaced with what was named the New Local Government policy. ${ }^{9}$

What had happened? The sudden demise of the BSRSF policy owed much to the ideological dissatisfaction and implementation difficulties experienced by government bureaucrats in trying to accommodate Indigenous ideas about 'regions' and representation for local government, and their consensus modes of decision making about these matters. Discussion and decision making took time, internal negotiation and sensitive facilitation - all of which challenged the capacity, commitment and resources of both the NT and Australian Governments. The political imperative for fast results chaffed at the more measured pace of voluntary regionalisation, and in the meantime, several NT community and

\footnotetext{
8 The Overarching Agreement On Indigenous Affairs Between the Commonwealth of Australia and the Northern Territory of Australia 2005-2010 and associated schedules are available at $<$ http://www.facsia.gov.au/internet/facsinternet.nsf/via/indigenous/\$file/IndigenousAffairsAgreement.pdf > [accessed 5 May 2008].

9 See 'Local Government Reform' on the DLGHS website at: <http://www.localgovernment.nt.gov.au/ new $>$ [accessed 5 May 2008].
} 
association councils had collapsed owing to poor financial administration and governance.

\section{Reverting to coercion}

The New Local Government policy framework attempted to contain the inherent slipperiness and flexibility of Indigenous governance institutions and decision-making processes. The policy did away with any formal recognition of culturally-based processes for determining local government regions, and effectively turned a blind eye to the potential for using Indigenous governance systems and issues of cultural geographies as the basis for the shire model.

Regionalisation was still the goal, but it was to be mandatory and meet government-imposed deadlines. To signal this major policy turnaround, Regional Authorities were renamed 'Shires'. There were to be only nine in total, and their boundaries would be determined by government.

Indigenous input was corralled into newly-formed 'Transitional Committees' created by government to provide it with 'advice' about the establishment of each shire. Government, private sector and non-Indigenous stakeholders were able to participate on these committees, widening the range of parties and views. An 'Advisory Board' was established to support the implementation process and provide recommendations to the Minister for Local Government. Its members and the Chair (an experienced Indigenous leader) were appointed by the Minister.

The new policy proposed that the shires:

will be democratically elected by the people, just like everywhere else in Australia. All councils including the municipals will have a minimum of six and a maximum of twelve councillors ... [and that] All Territorians who are registered on the electoral roll will have a say in who will represent their community by voting at the council election (DLGHS 2007).

A 'one-size fits all' approach was applied. The shires would have a single common governance structure, each with the same cap on the total numbers of representatives, and each sharing a single model constitution designed by the DLGHS and Parliamentary Counsel. All would deliver the same mandatory set of 'core' local government services, to be identified by government and set out in the new legislation.

In the early days of this NT policy reversal, in June 2007, the Australian Government responded to a damning report on child abuse in NT Indigenous communities (Anderson and Wild 2007) and, without notice to the NT Government, initiated a unilateral intervention to takeover the administration of some 60 remote Indigenous communities, including those in the West Arnhem region. 
As part of the intervention, the Australian Government would compulsorily acquire leaseholds for discrete Indigenous settlements for an estimated minimum period of five years. All communities located on Aboriginal inalienable freehold land under the Aboriginal Land Rights (Northern Territory) Act 1976 (Cth) (ALRA) would have their permit systems revoked, and legislation was drafted and passed to enact changes to this Act.

Australian Government administrators (to be called 'government business managers'), answerable to the Emergency Response Taskforce comprising Australian Army and Department of Families, Community Services and Indigenous Affairs and other government officials, were placed into 'priority' communities. Their job was to oversight mandatory health checks on children and to coordinate the intervention requirements in each community.

In late 2007, national elections were held and the Labor Party was elected as the Australian Government. In the early phase of its first term, it committed to evaluate the implementation of the NT intervention, whilst continuing with its basic strategies.

\section{Regionalisation in West Arnhem Land}

In the context of this hyperactive policy environment - with its extreme swings from collaboration to coercion and intervention - the Indigenous organisations and leaders involved in the West Arnhem initiative were forced to cope with several major, imposed changes of direction.

\section{The collaborative phase}

Indigenous leaders from West Arnhem community organisations became involved in the regionalisation process in mid 2003 as part of what was referred to as the 'Top End Triangle' (TET), comprising representatives from the Pine Creek, Coomalie, Kunbarllanjnja, Warruwi, Minjilang, and Jabiru local government councils. In December 2003, at a meeting of TET representatives, members of the Minjilang, Warruwi and Kunbarllanjnja Community Councils split from the other representatives in the TET group. They perceived there to be a lack of communal purpose between the Bininj and Balanda organisations, and felt that priorities were weighted to the latter.

The West Arnhem Land representatives began to see the potential for an 'Indigenous Regional Authority' and to work towards the establishment of what they eventually called the 'West Central Arnhem Regional Authority' (WCARA). ${ }^{10}$ At this stage, the nearby Jabiru Council stayed out of the process, and the Coomalie and Pine Creek Councils decided to proceed together in a separate initiative.

10 See Smith (2007) for a more detailed account of the West Central Arnhem regionalisation process during the WCARA phase, and the traditional patterns of land-tenure and social organisation involved. 
The initial leaders of the WCARA process were Bininj elected representatives from three community councils and two outstation resource organisations, including:

- Kunbarllanjnja Community Government Council;

- Warruwi Community Incorporated;

- Minjilang Community Incorporated;

- Demed Outstation Resource Association Incorporated; and

- Jibulwanagu Outstation Resource Association Aboriginal Corporation.

Together with their Chief Executive Officers (CEOs), up to three representatives from each organisation began meeting every six to eight weeks and, in August 2004, formed the WCARA Transitional Council with the goal of progressing discussions about amalgamation into a single regional authority. Representatives from the Local Government Association of the NT (LGANT) and the Commonwealth Office of Indigenous Policy Coordination also attended these meetings.

Interim Council members initially talked about the regionalisation policy both as an opportunity to secure greater authority and control for Bininj people over the things that mattered to them, and to exercise greater influence over government funding and service delivery to the region:

We will get to say what we want in our communities, we will set the priorities ... We have control over this project ... We will create policies and strategies that achieve more local employment and better services ... We will have a much stronger voice speaking as one to government ... The government always has a hidden agenda; we want our say from the word go (Members of the WCARA Interim Council).

The proposed area for the regional authority was approximately $25,000 \mathrm{~km}^{2}$-all of it inalienable Aboriginal freehold land under the ALRA. The area encompassed several inter-related language and landowning groups, three large discrete community settlements (two of which were on islands), and numerous small dispersed outstations (see Fig. 4.1).

The process was substantially facilitated by DLGHS and particularly through the efforts of two of its CDOs. From 2003 onwards, this male/female team travelled extensively throughout West Arnhem Land, disseminating information and holding discussions with community leaders and organisations about the BSRSF regionalisation policy. In doing so, they developed a large network of contacts with senior leaders and family groups, and built up strong relationships and considerable personal trust with local Indigenous residents. Through this community development approach, they facilitated the formation of the Interim Council and subsequently were asked to act as the secretariat for their meetings. 
Fig. 4.1 The proposed region for the West Central Arnhem Regional Authority, under the BSRSF policy

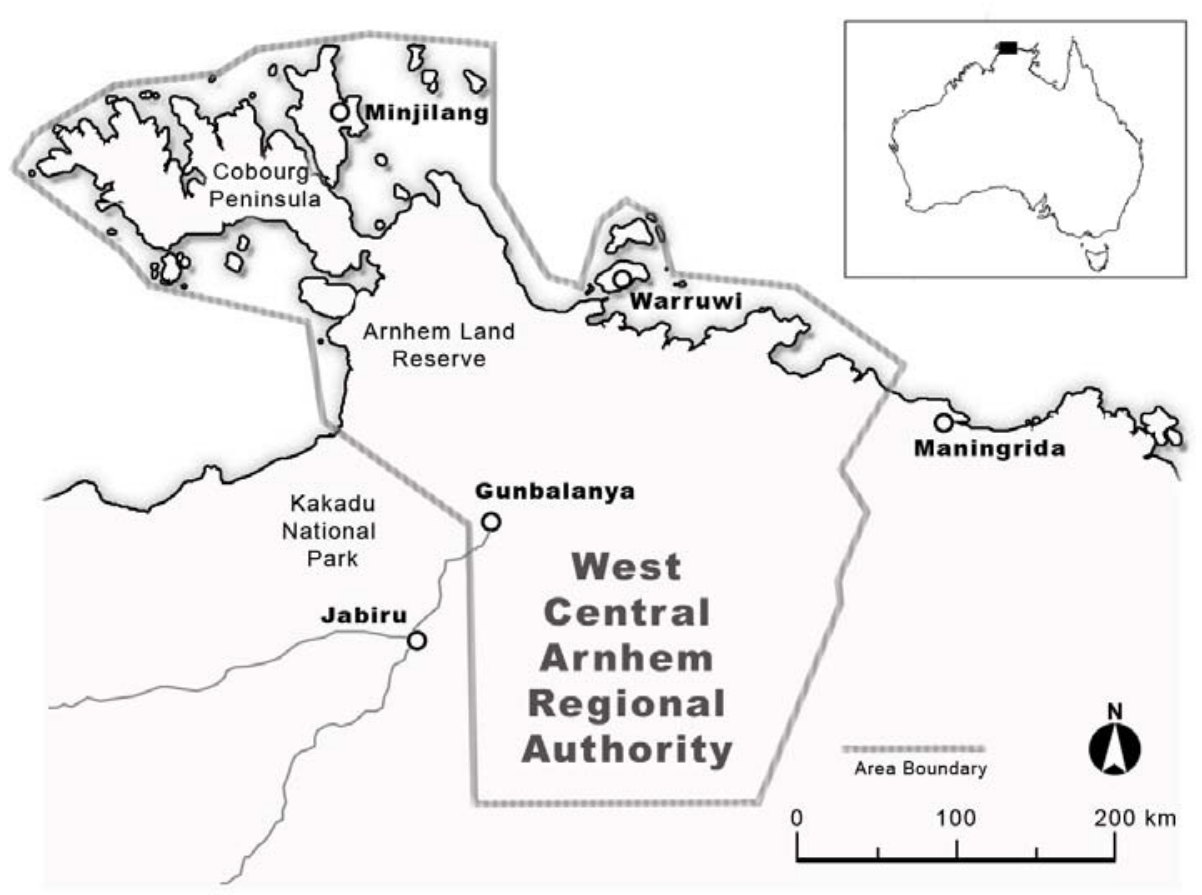

In mid July 2005, a 'Memorandum of Understanding' signed between the Department of Local Government, Housing and Sport (DLGHS) and the participating organisations formally committed all parties to support the decision-making work of the Interim Council to establish a regional authority for West Arnhem. A timeframe of December 2005 was proposed for its establishment.

Over that early period there was scepticism amongst community residents and Interim Council members about the extent of the NT Government's commitment to full Indigenous participation in regionalisation. Fears were expressed that the Government would simply impose a solution rather than negotiating with residents and their elected representatives.

Despite these reservations, the WCARA Interim Council met regularly between 2004-06. The workload was intensive for both the members and the departmental officers involved, as they navigated a complex organisational and legal transition. The proposed regional authority structure meant that the three existing community councils would have to be entirely dissolved as local government 
organisations. ${ }^{11}$ New election processes would also have to be designed and held for regional councillors, and the local government assets, functions, staff and administrative systems of the separate councils would have to be transferred across to the new authority. The BSRSF policy sought cost-sharing and resource efficiencies, so a rationalisation of some staffing positions was also proposed.

During this phase, the WCARA Interim Council made a number of collective decisions about the authority's governance and organisational structure, administrative arrangements, business planning, its system of representation, external boundaries, election procedures, headquarters, and service delivery roles (see Fig. 4.2).

\section{Fig. 4.2 Proposed representative structure for the West Central Arnhem Regional Authority}

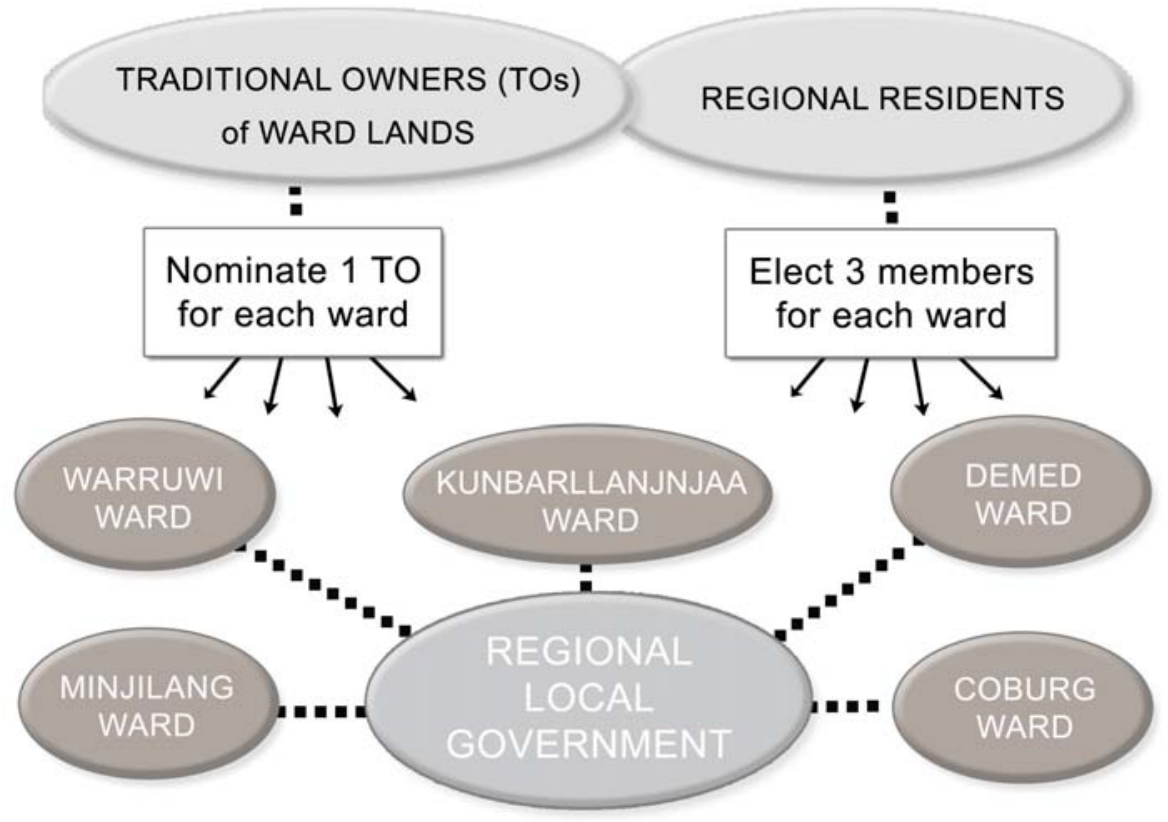

During 2005-06, the Interim Council participated in regular governance capacity-building sessions at their meetings, and spent considerable time developing a culturally-based constitution with a unique Preamble. A vision

\footnotetext{
${ }^{11}$ Kunbarllanjnja is a local government under the Local Government Act 1978 (NT) and so will be entirely dissolved; whereas Warruwi and Minjilang are Association Councils that are treated as if they are local governments by the NT Government for the purposes of receiving relevant government funding. They can maintain their organisational incorporation for other community purposes, but must transfer their local government type functions and funding to the new authority. Note that Kunbarllanjnja spelling was chosen by the Community Local Government Council as its name; Gunbalanya is the older form of spelling for the entire settlement.
} 
statement for the regional authority aimed: 'To develop safe communities for families, provide real jobs for local Indigenous people, and promote economic development through strong legitimate governance'.

Considerable work was involved in developing this constitution, designing a ward system for voting that was based on a Bininj cultural geography, and documenting a business plan for the authority. The process required considerable time and commitment from senior government bureaucrats, extensive community development work, as well as legal, funding and administrative support from both the NT and Australian Governments. To coordinate Government efforts, the DCDSCA convened a Project Management Group with officers from the NT and Australian Governments and LGANT. This inter-departmental group met every six to eight weeks over 2005-06.

But after the NT Labor Government was re-elected in 2005, its restructuring and renaming of the DCDSCA (which became the DLGHS) had significant consequences for the regionalisation process. In particular, the participation of government officers changed frequently on the Project Management Group for WCARA. Nevertheless, the group drafted a transitional funding framework for the region, considered mechanisms for streamlining the transitions to regional programs, and held interviews to employ a Transitional Manager to steer the administrative amalgamation of staff and community council resources.

Over three years had passed since the TET group first met. The Interim Council anticipated the establishment of the regional authority within just a few months. In late 2006, however, rumours abounded that the NT Government was contemplating changes to the BSRSF policy. In early 2007, a New Local Government policy was fully formulated by DLGHS and a detailed implementation plan put to the NT Cabinet for consideration. It required several NT Cabinet meetings in the first half of 2007 for the new policy to be officially endorsed. The policy was immediately implemented by DLGHS.

\section{Coercive implementation}

What did this mean for the WCARA Interim Council and participating community organisations, perched, as it were, on the brink of establishing their own authority?

First, the WCARA Interim Council was told by the Department that it would now be required to include Maningrida community and Jabiru township. The new 'region' was thereby extended to cover approximately $32,200 \mathrm{~km}^{2}$ and an estimated total population of some 5000-6000 people (see Fig. 4.3). 
Fig. 4.3 The required region for the West Arnhem Shire under the New Local Government policy
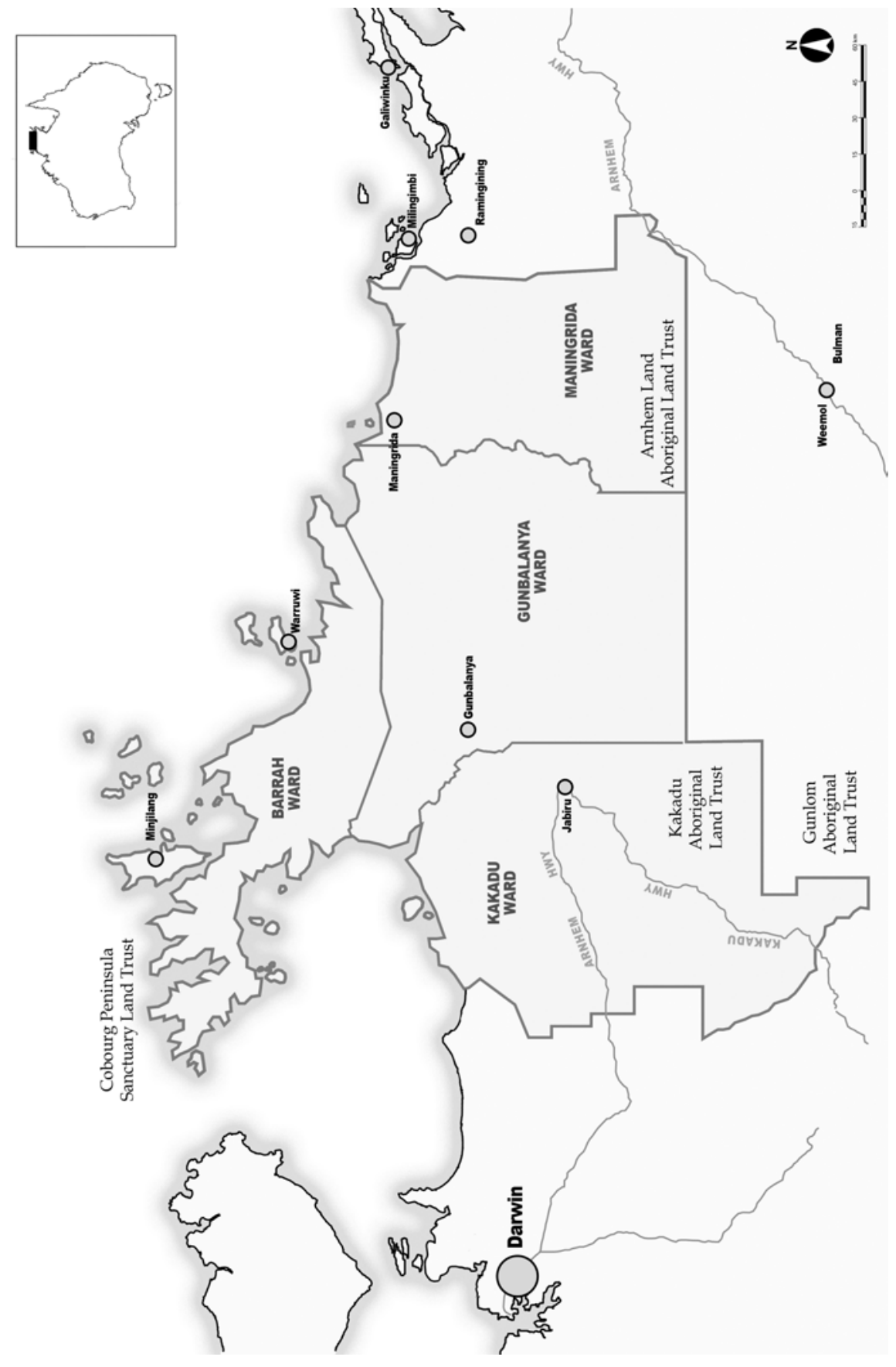
This larger shire involved an even more complex set of organisational and governance transitions. Like Kunbarllanjnja, the Maningrida Community Council is a local government under the Local Government Act 1978 (NT), and so would have to be entirely dissolved as a local government organisation and its relevant functions transferred to the new shire. Additional discussions would be needed with the Bawinanga Aboriginal Corporation, which provided services to numerous outstations, and with Jabiru town and its Council.

The mandatory inclusion of Jabiru confronted the WCARA Interim Council with a challenging issue - until then the proposed regional organisation included only Bininj communities and organisations, and covered inalienable Aboriginal freehold land. Jabiru's inclusion extended the region beyond the boundaries of Indigenous-owned land, which meant the Indigenous members of the Interim Council would have to accommodate a non-Indigenous town, its residents and elected representatives, and its different cultural values and priorities. In other words, a very different kind of regional local government was being proposed under the new NT policy.

Second, Interim Council members were extremely angry that their collective decision-making role had been usurped. They were told by the Department that they would henceforth be referred to as a 'Shire Transitional Committee' and have an identified consultation and advisory role. They would be required to provide their suggestions to the Advisory Board that serviced the NT Minister for Local Government, who would make all the final decisions about their organisational structure.

Decision-making power about the management, staffing, financial status and business plans of the new shire was abruptly reclaimed by government bureaucrats. A CEO was hired for them through a DLGHS process in which the new Transitional Committee had little involvement. A Transitional Shire Manager, who was an officer from the Department appointed by the Minister, became the legal face of the shire delegated to act as its decision-making Council, until such time as members were elected.

One committee member summarised the impact of the changes in these terms:

the NT Government is thinking ahead of us before we get to make our own decisions. It's running ahead of us. It's not even talking to us first about these things - so we are just talking about things that the government has already decided. We are already cooked - the cake has already been cooked by the government. We're not involved in making that cake; the government has made the decisions ahead of us (WCARA Interim Council Member).

Third, the Council was no longer seen by government to be 'representative' owing to its requirement that members from Maningrida and Jabiru should be 
included. A West Arnhem Shire Transitional Committee (WASTC) replaced the WCARA Interim Council, and a cap was put on the total membership by the Department. This meant that the number of representatives on the old Interim Council had to be cut down in order to include new members. Consequently, it was a smaller core of senior leaders from the Interim Council who moved across to the new committee.

Maningrida and Jabiru were initially unhappy to be told to enter into a regional process in which, until then, they had chosen not to participate. Not surprisingly, it took their representatives some time to familiarise themselves with the issues and decisions already made. Initially, they felt marginalised from what had become a very united team of representatives on the WCARA Interim Council.

From the point of view of the Interim Council members, they felt they were being told to start all over again, having to reconsider issues and decisions that they had already considered and made. They also realised that it would mean a considerable delay in the establishment of the new organisation.

Fourth, the culturally-based institutions that the WCARA Interim Council had designed, such as their constitution and preamble, were effectively thrown out. Also tossed aside was their solution for ward representation, which had sought to balance a Bininj nomination process for the single traditional-owner representative, alongside Balanda election procedures for three other representatives.

The overall effect was to relegate the Interim Council and its new Transitional Committee guise to a consultative, advisory role. The sense of disempowerment was felt keenly by all members:

Those foundations [for the regional authority] were built four years ago, and then they just get knocked from under us by the government. The horse hobbles are still there on us. That government just like a stockman sitting on the fence, they put the hobbles on us to keep us tied down. We've been put in the paddock and we've eaten every bit of grass. When our hobbles get rusty and we look like we might get out and free to eat some new green grass, someone just comes in and puts a new set of hobbles on us (WCARA Interim Council member).

But what was extraordinary at this point was that the WCARA Interim Council members decided to continue to participate in the process. The fact that they did is testimony to the significant headway they had made in working together as a team, and the effort they had put into designing their own governance institutions and making consensus decisions. As a consequence of this, they had developed a strong commitment to each other and to a shared vision of a future regional forum through which they hoped to exercise greater self-governance. They had also developed a significant sense of trust in the two CDOs working 
with them, whom they felt would continue to provide them with frank and robust advice about the new policy demands of government.

In order to stay engaged in the radically reshaped process, the Indigenous participants had to use every opportunity to strategically and persistently reinsert their own governance priorities and goals. This has included grappling with a non-Indigenous culture of governance within their meetings and negotiating a space for the development and exercise of their own institutions and values.

\section{Re-imagining Indigenous governance}

The Bininj leaders involved in this regional governance process have used their traditional rules, values and system of social organisation to re-imagine their contemporary governance needs and solutions. An important driving force behind this has been the desire to create a regional organisation that will better reflect Bininj cultural values and institutions: 'We will have a council that respects and works with our culture'.

Some of this re-imagining has been highly formalised; some has been spontaneously informal. Meetings of the Interim Council (and then the WASTC) were an important catalyst for designing workable governance structures and institutions, and highlighted the differences between Bininj and government expectations and concepts.

The 'glue' (cf. Cornell and Kalt 2000) of Bininj governance lies in its institutions; that is, in its own 'rules of the game', the way things should be done. These give legitimacy to practice, and include laws, kinship and marriage systems, behavioural and gender norms, family values, religious beliefs and moral system, principles of land ownership, ceremony and ritual, and so on (see Kesteven and Smith 1984; Smith 2007). Not surprisingly then, the creation and transformation of governance institutions became a focus for innovation, containment and contestation by Bininj and government bureaucrats alike.

\section{Constructing the region}

The tools and concepts employed by the state to construct the new local government 'region' diverged greatly from those of Bininj. The NT Government emphasised the need for an 'efficient' scale of population for local government and to have boundaries precisely mapped:

Half of the existing Territory councils are too small to provide and pay for the services that communities should expect to receive. Many of the councils are too small to attract experienced senior staff to run the services ... The shires will be big enough to negotiate with the Territory and Federal Governments on behalf of their communities (McAdam 2007). 
Rather than employing the cultural-community blocs recommended by the WCARA Interim Council, voters were to be congregated by requiring them to officially register against their place of residence as the basis for voting in particular wards. In the early phase of the BSRSF policy framework, Bininj leaders employed a 'cultural geography' in their construction of the new region. Their primary criteria for creating the external regional boundary was about 'who' should be included and excluded from the new region, on the basis of dense layers of traditional land-owning relationships and networks. In other words, the region and its boundary was, first and foremost, a negotiated interpretation by leaders of who legitimately constitutes the regional Bininj 'self'.

In the second policy phase of regionalisation, this internal reading of the cultural boundaries of relatedness was forced to expand as a result of the above-mentioned mandatory inclusion of the Maningrida and Jabiru communities - neither of whom was initially included under Bininj criteria for the proposed region.

To this extent, the new, larger shire boundary has been an evolving compromise between Bininj concepts of what is the culturally relevant geography for the region, and the NT Government's consideration of what constitutes the best scale to secure its goal of greater cost and service delivery efficiency. In this instance, the legal and policy powers of the state enforced a major constraint on the re-imagined Bininj regional 'self'.

Nevertheless, throughout the process, Bininj leaders continued to generate a correlation between their core cultural metaphor of 'one family' and the proposed region:

We need to stick together and look after each other ... It [the committee and proposed regional shire] has brought families together in the region ... We have had to work hard and we have become one big family (WCARA Interim Council members).

The overarching Bininj metaphor of 'one family' denotes a core institution that underlies individual and kin-group identity. It has been used frequently by members of both the WCARA and WASTC to invoke the values of mutual support and reciprocity, loyalty, and shared work efforts that are seen to lie at the heart of Indigenous 'family' life. Its use in the regional context seeks to imbue the proposed shire and its governance arrangements with the cultural legitimacy derived from the concept of 'family'.

This metaphor also has a domesticating power. The leaders on the earlier WCARA Interim Council have continued to invoke it during WASTC meetings in order to extend the 'ties that bind' to the newly included communities of Maningrida and Jabiru. Their purpose has been to ease the transition of the new committee 
members from the status of 'strangers' or 'outsiders' to being part of the close family that is forming a new 'collective self' for regional local government.

At every point of engagement in this convoluted and complicated process, the Bininj leaders have denied the ordering power of the NT Government's approach to creating boundaries for the region and its composite wards. During a discussion about the newly imposed external boundaries, one leader succinctly expressed an opinion that was common within the earlier Interim Council:

In the Balanda word that will be a boundary there. But it's just a service line. It's just a line for the government. You see this line? It's not there. We're not going to trip over that boundary line when we're walking out on our country. This line is local government, it's not for traditional owners' land - we know our own land, every little place; long time, from start' (WASTC member).

The Bininj members of the Council/Committee are themselves traditional owners and have consistently argued that regionalised local government should not impinge on their cultural and legal rights under the ALRA. From the start, they have been keen to ensure their decisions do not undermine those primary rights, or exacerbate tensions over land ownership. For that reason, they initially decided there should be no mapped internal boundaries for the proposed electoral wards. These were to be kept deliberately invisible so that they could continue to be managed under the Bininj system of knowledge and control of country. However, the current policy requires that all shire internal ward and external regional boundaries be mapped and made visible.

In the Bininj-government interplay that continues over the issue of boundaries, the Bininj representatives continue to reinforce the importance of locally relevant cultural geographies as the foundation for their governance solutions. They strategically use this ordering mode to resist the externally imposed institutions of government, which work to re-group and re-order Bininj people into neatly bounded geographies:

We said to people [out in communities] don't be worried about that line out there. That's a service line. They think it will cut them off from everyone else. But it's not a line for Bininj land. Your right cannot be disturbed by that idea (WCARA Interim Council member).

\section{Seeing the pattern of Indigenous governance}

The pattern of traditional Bininj governance, visually reproduced in much of their art, ceremony and ritual can be understood as a 'nodal network'. This type of network is formed by the interconnectedness and interdependence of essentially autonomous units and actors (each constituting 'nodes'), where the constituent linkages can facilitate or inhibit the functioning of the overall system. 
A 'governance network' then refers to the interconnected distribution and exercise of a group's decision making and leadership to achieve their collective goals.

Bininj governance networks in West Arnhem Land comprise clan groups, inter-related by complex webs of kinship, land-ownership identities, marriage systems, historical alliances and ceremonies (see Kesteven and Smith 1984; Smith 2007). In these networks there are 'nodes' or points of individual agency and decision making, where particular male and female leaders who have respect and influence are able to mobilise people and resources to create order and collectively get things done. In highly decentralised systems of social organisation like those in West Arnhem Land, governance nodes such as leaders and organisations enable decision making to coalesce and be implemented. In this system, nodal leaders constitute the circuitry of governing order and authority that enables things to be achieved over time.

Bininj networked governance in West Arnhem can be deciphered, although it is often invisible to outsiders. It has its own culture or world view - a way of thinking about the matters that need to be governed, and ways of reproducing the patterns of interconnectedness that underlie the networks needed for governance. It has a set of technologies, powers and processes for exerting influence and power, and for prompting action amongst people. It is able to marshal resources via nodal leaders and organisations. And it employs a set of institutions, or rules, which enable nodal leaders to legitimately activate governance networks.

The Bininj members of the WASTC are part of nodal leadership networks that stretch across West Arnhem and well beyond. They have striven to create a representative structure for the regional authority, and now the shire, that is based on their governance culture of nodal networks. Much of their effort and motivation has not been immediately intelligible to Balanda in the region, or to government officers. And when they have become intelligible, Bininj proposals are not always acceptable to Balanda, who have different ideas of what constitutes 'good', 'effective' and 'legitimate' governance.

The NT Government and its departmental officers insist that a democratic standard be applied to the future number and election of shire representatives. Representation, they assert, should properly be based on the total population of each constituent ward in the region: 'Under New Local Government, councils will be democratically elected by the people, just like everywhere else in Australia' ${ }^{12}$

As one NT Government officer stated at a WASTC meeting:

\footnotetext{
12 See DLGHS website, 'Governing', <http://www.nt.gov.au/localgovernment/new/ministers_update/ governing > [accessed 5 May 2008].
} 
The next complexity factor for us [government] is, this is a democracy and everyone should have a vote - one person, one vote. Another challenge is remoteness and the dispersed nature of the population, plus the cultural groupings of small communities. These can't be the basis for wards and representation. We don't want loose cultural groupings, but we want bigger wards so that we keep the total number of representatives to ten or twelve.

Bininj members of the committee see this interpretation of democracy as being fundamentally at odds with their own governance institutions. They feel it to be unfair and unequal. From their perspective, representatives are seen as:

people who have got picked by their communities and elders in their area. They didn't just come for nothing. It's each council and elders who picked those people to represent their people. When we first started off we wanted everyone to be equal (WASTC member).

The Bininj view of 'equal' is based on each main cultural-community bloc having an equal number of representatives for each ward, irrespective of the population or geographic size of the ward:

Our main issue is that it is 'all equal', so we don't upset people. We have to be very careful. Every person out there knows we are working together on this - we got a jury out there. When we go back to our community we have to behave properly and make our decisions properly so people in our communities can see us paying respect and behaving properly.

... We decided we wanted three reps for each ward because they are the right people; not on a population basis. Remember we talked about that [i.e. representation] three years ago, and we said each ward should get 'equal vote', 'equal number'; that's fair for everyone' (WASTC members).

There is disquiet about this view of equality amongst some Balanda CEOs on the WASTC who work for councils in the communities that have a large population. They too stress the democratic benchmark of 'one person, one vote'. But at several committee meetings about the issue, the Bininj members - including those from the communities with large populations - reconfirmed their strong preference for having an equal number of representatives for each ward. They also pointed out to government officers that the Bininj approach was in fact similar to that of the Australian Senate in its representative arrangements.

Bininj leaders continued to apply the same logic of 'all equal' to representation for the proposed shire; that is, each major community with its participating council and outstation organisation would have an equal number of representatives regardless of population size (see Fig. 4.4). 
Fig. 4.4 The proposed representative structure for the West Arnhem Shire under the proposed New Local Government policy

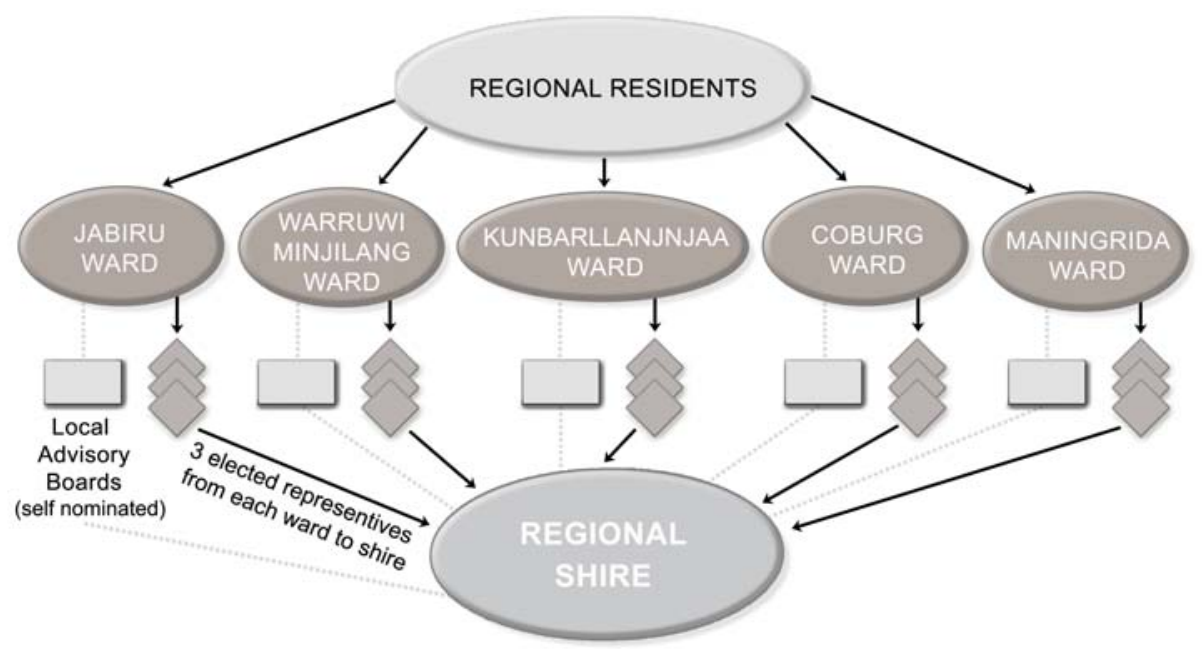

Negotiations about this are continuing between committee members and departmental officers. The Advisory Board is attempting to operate as a go-between for the WASTC, putting their views forward to the Minister and supporting the value of their cultural logic.

This is an important issue for committee members who are attempting to reconcile the two different cultures of governance operating in the process, at the same time as striving to arrive at a culturally legitimate solution that will gain the backing of their community members. Bininj members prefer to take major governance issues back to their communities for further consideration. This has meant considerable discussion and negotiation within the committee and the participating organisations.

\section{Governing 'two-ways'}

An early activity of the Bininj committee was to design a logo ${ }^{13}$ for the WCARA. The logo is a visual map of the regional Bininj 'self' (see Fig. 4.5). It depicts two turtles - one saltwater, the other freshwater - to indicate the inclusion of people from the coastal and island communities, as well as the inland communities of West Arnhem. The turtles allude to the ancient interaction between two mythological creatures, and 'the two coming together' to resolve their differences. The logo also depicts Bininj and Balanda hands clasped together, to symbolise

\footnotetext{
13 The logo for the WCARA was chosen from a regional design competition. The winning design was created by Mr Ahmat Brahim, an Indigenous man with traditional ties to the region, and whose father has been a member of both the WCARA Interim Council and the WASTC. The transitional committee later affirmed their choice of the logo for its new shire.
} 
the two collaborating for the benefit of all residents of the region. This vision was expressed by one committee member as 'working two-ways'.

Fig. 4.5 The proposed logo of the West Arnhem Shire Transition Committee and the former regional authority
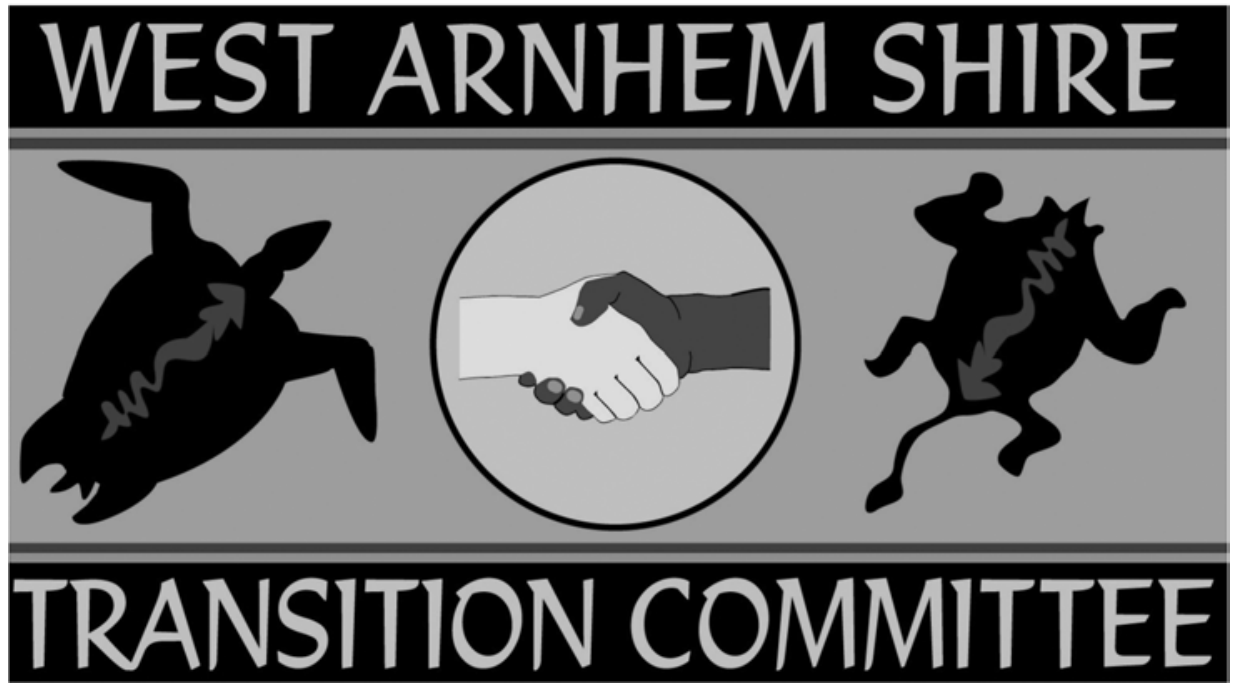

The WASTC readily adopted the logo as being a positive symbol of how Bininj and Balanda could work together as a shire. As one senior member of the committee explained:

This is how we are working two ways. We are using our Arrarrakpi

[Bininj/Indigenous] concept and using it with this Balanda concept.

The WCARA constitutional preamble drafted by the Interim Council also embedded this 'two-way' approach, stating that:

This Preamble is grounded in the traditional Aboriginal law, language and systems of self-governance for the region. It brings this view to the implementation of local government administrative systems that provide service delivery to all peoples of our area.

The WASTC adopted the preamble, confirming their intention to continue to use Bininj traditional systems of culture and governance in order to:

strengthen the legitimacy of the Regional Authority [shire], and use the [shire] to strengthen traditional systems of governance. Through this vision and commitment we seek to maintain observance and respect for traditional values, and to join the responsibilities and structures of traditional authority with those of local government to achieve a high quality of life and a wide range of opportunities and choices ... We are developing our own rules that include our culture. In our own culture 
we have our own rules that are very strong and we are bringing this into the [regional local government].

The logo and preamble subsequently became important devices for positively accommodating Jabiru Town Council and its largely Balanda population. As one committee member noted: 'It's [the logo] a good one because the handshaking now takes in Jabiru as well. It includes Balanda as well'.

The principle of 'working two ways' to develop governance solutions for the new shire has, at its core, a Bininj process of innovation and active adaptation. A consistent benchmark has been the Bininj committee members' need to ensure that the process has internal cultural legitimacy.

This process was contested by government. For example, a component of the new policy was the NT Government's requirement that all shires adopt a single common constitution. This effectively meant that the WCARA preamble and constitution were no longer relevant. Over several meetings, however, the newly formed WASTC Council negotiated through the Advisory Board that the preamble could become part of the shire's business plans (which were being developed by departmental officers). They also began compiling a Governance Reference Manual of their draft policies and decisions to guide future elected shire representatives and managers. They subsequently gained departmental agreement to have the preamble and governance manual included as an official document in the shire's strategic development plan. These were significant breakthroughs.

\section{Transforming institutions}

Over the four-and-a-half years of their operation, a number of formal and informal governance institutions (rules) have been generated by the Interim Council and Transitional Committee. This 'rule innovation' often occurred in the course of their meetings. It was there that members attempted to create workable solutions to some of the challenging problems caused by the disjunctions that kept arising between the two cultures of governance.

The litmus test at meetings was that Bininj-generated rules needed not only to be seen as culturally legitimate, but to be immediately useful. If they were, then committee members adopted them quickly. For example, in the middle of one committee meeting when new members had arrived, the chairperson announced to all participants:

I don't like to say people's name. Bininj way, I can't say that name. So when you move and second a resolution can you please say your name out loud yourself so you can have your name put down on the minutes.

The chairperson effectively resolved what might otherwise have been an awkward situation for himself by designing an impromptu procedural rule that enabled him to continue directing the passage of resolutions in the formal Balanda 
style, without having to forgo his observance of an important Bininj etiquette rule that restricted his public use of people's personal names. The new rule was immediately acted upon as everyone could see its practical benefits for themselves as well as for the chairperson.

At the beginning of another meeting, before the commencement of business, a committee member made an announcement:

Before we start with that agenda I just want to say something about my cousin sister's boy over there [referring to a young man sitting across the table who had recently been chosen by his community council organisation as a representative on the committee]. Well, Bininj way, that boy can't look at me or talk to me-nothing. He shouldn't be sitting here in this room. I talked to his mother last night and we decided that for these meetings he can talk to me and he can speak up. He comes here, he's got to do his job. That means he might have to talk to me and I gotta listen to him talking about his idea. But Bininj way he would get into trouble if he does that. So, just for these meeting here, we making a new rule: he can talk and look at me. But only here, not for outside; that still Bininj way out there.

In response to this statement, the other committee members at the meeting (both Bininj and Balanda) made supportive comments and agreed to the new rule.

In this instance, a senior leader and his close relative had designed a new rule that had the hallmarks of the cognitive tool of compartmentalisation. This process enables people to organise things (ideas, events, relationships) into discrete units or categories, each of which has its own properties of boundedness and isolation, at the same time as having some form of limited or controlled relation with the other parts (see Spiro and Jehng 1991; Strauss and Quinn 1997). Cognitive compartmentalisation is a particularly useful tool in intercultural contexts. It means that seemingly contradictory ideas or behaviours can be observed and held, without either being undermined or elevated over the other.

In the example above, a new rule was created for a specific context, which addressed a widely recognised kin-based behaviour that required certain kinds of avoidance and deferential behaviour to be observed between two classes of relatives. Failure to observe the avoidance rule would incur family and public censure, and perhaps, retribution. The new rule enabled the WASTC members who stood in such a kin relationship to each other to effectively suspend the accepted customary rule of kin avoidance and so behave differently in the meeting. Outside the room, at breaks in the meeting, the norm of avoidance behaviour quietly reasserted itself.

By compartmentalising this 'meeting behaviour' under a new rule, the potentially negative consequences were not only ameliorated for the individuals concerned, 
the new behaviour was also disambiguated. That is, it was made collectively comprehensible to all the other members of the committee, and able to be assessed by them as being culturally legitimate owing to the fact that it was a derivative of the more fundamental customary norm. This became an accepted process of rule transformation at the meetings.

An important effect of this process of cognitive compartmentalisation is that the cultural authority of underlying customary institutions is buffered from the potentially negative impacts of contradictory new rules by those contradictions being contained and nullified. Compartmentalisation also enables the Bininj worldview of the continuity and inalienability of their laws to be maintained, at the same time as allowing condoned institutional innovation to occur.

Other examples of rule innovation have occurred at meetings in the more formal context of governance capacity development and training sessions. These sessions have been conducted with Bininj representatives from the very beginnings of the regional initiative, and have been provided by the same male and female team of CDOs from the DLGHS, with personal input from my governance research (see Evans, Appo and Smith 2006; Smith 2007).

The training sessions focused on a wide range of governance issues including governing roles and responsibilities, the concept of separation of powers, systems of representation, organisational models to support regionalisation, policies for codes of conduct and conflict of interest, meeting procedures, human resource management and employment contract conditions, communication with community residents, and so on.

In each session, the Bininj committee members discussed the non-Indigenous concepts and values, alongside their own. They raised a range of cultural issues that might potentially undermine the legitimacy and enforcement of new governance rules. They tested proposed rules against potential community and cultural scenarios, and revised them to enhance their workability and legitimacy. Members often shared ideas about how they might collectively and individually enforce their governance policies and rules. Each session culminated in the committee drafting new governing institutions, for example, in the form of written policies, agreed procedures and resolutions. Through this process, the Bininj leaders on the committee steadily developed a growing confidence in their capacity to work together as a team, and to make and enforce collective decisions, policies and other rules.

In these situations, committee members have been creating shared meanings about their expected and actual behaviour, roles and responsibilities, which then provide the groundwork for forming new governing rules. The rules that work most effectively are those which appear to fit four fundamental criteria. 
First, they give priority to people's pre-existing cultural knowledge, norms, systems of authority, and experiences. Second, they have been designed collectively and in a practical governance context. Third, they can be put to immediate practical use; and fourth, they can continue to be adapted to suit changing governance needs.

As Spiro and Jehng (1991: 163-205) have noted, this calls for considerable cognitive flexibility at both an intra- and inter-personal level. It suggests that a Bininj culture of governance is created and maintained through interaction and practice. This enables nodal leaders to act as instigators of new and old meanings, and to mobilise consensus and action around those. That is, nodal leaders are able to tailor concepts and social value to create new institutions in ways that have legitimacy in the eyes of the rest of the network. Importantly though, Bininj innovation and practice are firmly located within an intercultural frame. Legitimacy and effectiveness are judged and shaped as much by the concepts and institutions of the state as those of Bininj people.

Conversely, when governance institutions are imposed from the outside and have no grounding in the pre-existing meanings and experience of Bininj culture, those rules have a weak hold on people's values and behaviour. Such externally generated rules cannot be easily compartmentalised and so can undermine existing cultural institutions of governance. They also tend to have less cognitive flexibility and therefore cannot easily be customised or reassembled by Bininj to meet changed circumstances.

\section{Conclusion}

In the second phase of its policy reform agenda, the NT Government sought to reassert its own culture of governance in an attempt to contain, mould and rename Indigenous systems of governance and their attendant institutions, and in an effort to hasten the process of regionalisation. In the course of working to achieve their goal of a strong regional organisation, Bininj community organisations and their elected leaders have attempted to design elements of a new 'culture of governance'. To do this, they have used formal and informal techniques and tools to create innovative governance institutions and structures, and imbue them with legitimacy and practical capability.

At its heart, the intercultural contest occurring within the West Arnhem initiative is over power and authority itself:

They don't trust us to make our own decisions. There has been a lot of terminology that has been used in the history of this shire, and that term is democracy. Can you define what democracy is for us? We keep hearing about it, but we don't get to do it. We don't get to make our decisions about these things. 
... I don't see any democracy - you just get told what to do: lump it, or do it ... What kind of message do we take to our people? Do we just tell them that in two years down the track we will have the power maybe; that sometime in the future we will get to make the decisions? Poor bugger blackfella that's what we are (WASTC members).

Committee members overwhelmingly see this intercultural contestation as more than just a struggle for regionalised local government. It is a process by which they hope to secure greater self-governance and control over the longer term. It remains to be seen whether regionalised local government delivers on its promises and expectations in West Arnhem. In the meantime, there is much that can be learned from the process to date.

The new NT Government policy framework states that its:

intention in seeking [its latest] fundamental reform of local government is to create certainty and stability through strong regional local governments that will have a similar capacity to that of the municipal councils ... The need is for orderly transitional and implementation arrangements (McAdam 2006).

But policy implementation has been anything but orderly. This is more than simply a consequence of the real world complexities of implementation catching up with the policy vision. The local government reform process has been wracked by problems created by the institutional failings of the government's own culture of governance, including differences of political opinion within the government and cabinet. Several NT Ministers have appeared reluctant to commit to the New Local Government policy, preferring the more flexible and culturally-inclusive approach laid out in the BSRSF.

In 2008, erratic government commitment to its own policy led to the NT Cabinet allowing non-Indigenous residents in the Litchfield region west of Darwin to opt out of regionalisation, while still requiring Indigenous residents in other regions of the NT to continue. As a consequence, some of the Indigenous communities who were told in early 2007 that they had to amalgamate into larger regions are now questioning why they should continue to be involved, or why they need to rush to meet a government-imposed deadline of the middle of $2008 .{ }^{14}$

Another recent Government decision to set an unusually low cap on the rate payments from pastoralists and the mining sector caused considerable disquiet

\footnotetext{
${ }^{14}$ A media release by LGANT (2008) noted that following this decision 'other councils are asking about the Government's processes and timetable for bringing in the reforms ... The Government's action in abandoning the Top End Shire proposal has set a precedent which is leaving councils with an emerging feeling of mistrust, of being led to believe one thing only to find it has changed dramatically to something else. They say they are losing faith in the Government's plan since the resignation of the previous Minister and since the change was introduced'.
} 
within the bureaucracy and amongst several members of the WASTC. ${ }^{15}$ In this highly charged environment, in mid 2008, the NT Minister responsible for oversighting the New Local Government policy and two senior departmental officers resigned. These officers were centrally involved in the West Arnhem Shire process.

The WASTC has not been surprised by the erratic governance of government, with all its policy reversals, changing implementation rules, and rapid turnover of bureaucratic faces at their meetings. The nub of contention for committee members has consistently focused on whether they actually have genuine decision making powers or not. This issue has especially arisen in the context of departmental reassertion of its decision making powers under the New Local Government policy. Consequently, implementation of that policy has been transformed and contained by its engagement with persistently asserted Indigenous governance institutions and agency.

Today, a growing number of Indigenous Australians are re-imagining what constitutes legitimate representation, decision making and leadership for their community governance arrangements. They are doing this at different societal scales and experimenting with models of governance. More specifically, the West Arnhem case study describes the ways in which principles of networked governance, nodal leadership, institutional innovation, and the cognitive tools of compartmentalisation are being used-both consciously and unconsciously - by Bininj people as interpretative instruments with which to design new governance arrangements that suit larger scale cultural geographies and retain cultural legitimacy.

Indigenous leaders play a pivotal role in mobilising deep-seated cultural understandings and imperatives in order to do this. When their transformations and experiments have resonated with their peer network of leaders and with their members (their 'jury'), and are judged to be 'fair' and 'equal' in Indigenous terms, then the new rules and structures have gained internal legitimacy. In this way, it has been the nodal leaders and their networks who have created an internal culture of governance, but it is the 'governed' (the 'jury' of community members) who have enabled new governance institutions to be implemented and sustained.

To be imbued with legitimacy, new governance institutions have to be tested and proven useful in the real world. If new rules and ways of looking at governance prove workable and legitimate - not only in the Indigenous arena, but in the wider intercultural arena of government policy - then they may receive endorsement within the policy implementation processes. But if

\footnotetext{
15 LGANT estimates that the regional local governments in the NT will lose between \$14-18 million in foregone rates from pastoral and mining industry as a result of the NT Government decision.
} 
governance rules are imposed by external agents, or if they cannot be enforced without damaging fundamental Indigenous cultural values and ways of behaving, then those governed will inevitably deliver a verdict of failure and resist the application of the rules.

There are limits to the extent to which Indigenous Australians can currently transform and reassemble their institutions of governance. One set of constraining factors lies within Indigenous cultures of governance themselves. In West Arnhem Land, the Indigenous cultural drive towards localism and small-scale autonomy acts to impose social limits to political aggregation. When internal legitimacy and trust waver, the group to be governed tends to default back to small localised networks of close kin.

As a consequence, there can be significant difficulties in sustaining the horizontal social spread of new governance institutions. Indigenous networks - especially those of leaders - can facilitate this horizontal extension, in particular to the regional level. But transforming and deepening the legitimacy of Indigenous institutions to enable larger scale cultural geographies of governance requires time, facilitation and ongoing discussion in order to generate the wider consensus and support needed at the local levels.

New governance institutions that appear to preference the rights and interests of some groups or individuals over others, or which diminish valued group norms, do not generate sufficient cognitive or cultural traction to sustain their ordering power. Nor will they be sustained if they are unable to accommodate the layered and networked nature of power and decision making in Indigenous societies. Institution building that is based on the flexible reassembly of pre-existing Indigenous norms and ideas about what is 'equal', 'proper' and 'fair' appears to have greater effectiveness, both in meeting the challenge of new situations and in winning the support of the members of a community or organisation.

Another significant factor limiting Indigenous transformation of governance institutions arises from the external environment. Contemporary Indigenous governance initiatives are embedded in, not separate from, the institutions and power of the state and its culture of governance. In Australia, the state exercises overwhelming jurisdictional, institutional and financial powers through which it governs Indigenous culture and seeks to make Indigenous governance and people 'good' in western terms. As one member of the WASTC summarised this relative power imbalance:

We Bininj have small power, only little backstop, just one backstop. Whitefellas, government, got plenty backstop behind them. They can come in any time and tell us what to do. They got the power. 
But Indigenous processes of institutional transformation have the power to subvert, contain and modify the agenda of the state's own culture of governance and its efforts to govern Indigenous culture. This partly explains why, in Australian Indigenous affairs, policy implementation inevitably becomes disorderly and uncertain, leading to processes and outcomes on the ground that are often entirely different from those originally intended. This has been the case in West Arnhem Land.

Indigenous societies do not exist frozen in time as outdated 'cultural museums' (cf. Vanstone 2005). They have a long history of highly sophisticated innovations in their governing institutions. Furthermore, Indigenous leaders are often adept at connecting into non-Indigenous policy, bureaucratic nodes and political networks in order to achieve their own priorities. Astute government officers who pay attention to, and build relationships of trust into, those networks are themselves better able to act as intermediaries between the two cultures of governance, and to carry out community development work to support governance initiatives at local and regional levels.

From this it is clear that in order for contemporary institutional transformation of Indigenous governance to be effective and sustainable a number of conditions must be met. First and foremost, new governance institutions must be initiated by Indigenous people themselves on the basis of their informed consent. Second, the role of trusted and respected leaders is critical to institution building. Third, it must be undertaken in ways that resonate with community members' views of what is considered to be culturally legitimate and practically workable. Fourth, external coercion and the imposition of governance institutions have little traction in changing behaviour or building commitment and responsibility. And fifth, the facilitation and community development work of trusted government officers can make a major contribution to the implementation of enabling policies about governance.

But it appears that in these matters the state is a slow learner; or rather, in the case of West Arnhem regionalisation, its desire to retain decision making power and control appears to have inhibited its learning and outcomes. In some ways, the state has been less innovative than Bininj in designing effective institutions to carry out its governance objectives. In the end, the state seems to have failed to recognise the value and benefits of Bininj decision making, to see that Bininj leaders can resolve complex governance problems with innovative strategies, and that their solutions can actually facilitate government policy implementation. In the end, it may well be that regardless of the power differential the Bininj understanding of the state's governance culture is greater than the state's comprehension and control of Bininj governance culture. 


\section{Acknowledgements}

I would like to take this opportunity to thank the management and staff of the DCDSCA and the restructured DLGHS, who provided me with collegial support and engaged in robust debate over many Indigenous policy and local government issues. I would especially like to thank Leanne Evans and Harry Appo, the two Community Development Officers, for the opportunity to work alongside them over five years. Their considerable professional knowledge and practical expertise in community development, built up over many years working with Indigenous leaders and community organisations, contributed enormously to my work and insights. Needless to say, the analysis presented here is my own and does not reflect the official position or opinions of DLGHS or any of its officers.

The opportunity to work with the Indigenous members of the WCARA Interim Council, and then the Indigenous and non-Indigenous members of the West Arnhem Land Transitional Committee, has been especially rewarding for me. I would like to thank them all for their ongoing friendship, support, openness, humour, and critical feedback on my ideas, and for the opportunity to participate in their challenging Bininj discussions.

In regard to this paper, I would like to thank the ICGP research team for their feedback during a workshop we specifically convened to discuss contributions to this edited volume. I also greatly appreciate the insightful comments from Janet Hunt, Sarah Holcombe, Stephanie Garling and Neil Westbury, as well as the very useful critique made by anonymous referees.

\section{References}

Ah Kit, J. The Hon. 2002. 'Ministerial statement', delivered as Minister assisting the NT Chief Minister on Indigenous Affairs, 7 March, Northern Territory Parliament, Darwin.

-2003. 'Building stronger regions - stronger futures', Speech as NT Minister for Community Development to the Local Government Association of the Northern Territory, 14 May, Alice Springs, available at $<$ http://www.lgant.nt.gov.au/lgant/layout/set/print/content/download/ 248/749/file\%20Speech.pdf?PHPSESSID=5a3aa6c5c2599f135f627lbla4461c16> [accessed 15 May 2008].

Anderson, P. and Wild, R. 2007. Ampe Akelyernemane Meke Mekarle-Little Children Are Sacred, Report of the Northern Territory Board of Inquiry into the Protection of Aboriginal Children from Sexual Abuse, Report to the Northern Territory Government, Darwin, available at $<$ http://www.nt.gov.au/dcm/inquirysaac/>

Behrendt, L., McCausland, R., Williams, G., Reilly, A. and McMillan, M. 2007. 'The promise of regional governance for Aboriginal and Torres Strait 
Islander communities', Ngiya: Talk the Law, Governance in Indigenous Communities, 1: 126-66.

Coles, D. 2004. 'Representative Authorities: Towards representative structures and service delivery to meet the Northern Territory's needs', Unpublished paper presented to the Sustainable Economic Growth for Regional Australia conference, 6-8 September, Alice Springs.

Cornell, S. and Kalt, J. P. 2000. 'Where's the glue? Institutional and cultural foundations of American Indian economic development', Journal of Socio-Economics, 29 (5): 443-70.

de Alcantara, C. H. 1998. 'Uses and abuses of the concept of governance', International Social Science Journal, 155: 105-13.

Department of Local Government, Housing and Sport (DLGHS) 2007. 'Governing', New Local Government Fact Sheet, Northern Territory Government, available at <http://www.localgovernment.nt.gov.au/new/ community_engagement/fact_sheet_updates> [accessed 15 May 2008].

Evans, L., Appo, H. and Smith, D. E. 2006. 'Community development practices and principles in the development of the West Central Arnhem Regional Authority', Unpublished paper, Department of Community Development, Sport and Cultural Affairs (DCDSCA), Northern Territory Government, Darwin.

Hirst, J. 2007. 'The myth of a new paternalism', The Australian, 26 June, available at <http:/www.theaustralian.news.com.au/story/0,20867,219662577583,00.html $>$ [accessed 24 April 2008].

Holcombe, S. 2005. 'Luritja management of the state', Oceania Monograph Special Issue, Figuring the Intercultural in Aboriginal Australia, M. Hinkson and B. Smith (eds), 75 (3): 222-33.

Howitt, R. and Suchet, S. 2004. 'Rethinking the building blocks: Management and Indigenous epistemologies', Paper presented in the 'Processes for Cross-Cultural Engagement-Remote Regions/Northern Development' session of the Western Regional Science Association Meeting, 26-29 February, Wailea Marriott Resort, Maui.

Kesteven, S. and Smith, D. E. 1984. Contemporary Land-Tenure in Western Arnhem Land: An Investigation of Traditional Ownership, Resource Development and Royalties, Report to the Australian Institute of Aboriginal Studies and the Northern Land Council, Darwin.

Kooiman, J. 2003. Governing as Governance, Sage Publications, London.

Local Government Association of the Northern Territory (LGANT) 2003. 'Submission to the Standing Committee on Legal and Constitutional Affairs into an Examination of Structural Relationships in Indigenous 
Affairs and Indigenous Governance within the Northern Territory', Darwin.

2008. 'Storm front brewing for local government reform', Media Release, 20 February, available at <http://www.lgant.nt.gov.au/lgant/content/ view/full/1930>.

McAdam, E. The Hon. 2006. 'Minister's Speech' as Minister for Local Government, Local Government Association of the Northern Territory (LGANT) Conference, 11 October, Alice Springs, available at $<$ http://www.localgovernment.nt.gov.au/new/minister/ministers_speech> [accessed 15 May 2008].

2007. 'New Local Government', Message from the Minister, DLGHS brochure, Northern Territory Government, available at <http://www.localgovernment.nt.gov.au/_data/assets/pdf_file/0005/9698/ Local_Govt_Brochure_web.pdf $>$ [accessed 5 May 2008].

Moran, M. 2002. 'The devolution of Indigenous local government authority in Queensland: Opportunities for statutory planning', Australian Planner, 39 (2): 72-82.

Morphy, F. (ed.) 2007. Agency, Contingency and Census Process: Observations of the 2006 Indigenous Enumeration Strategy in Remote Aboriginal Australia, CAEPR Research Monograph No. 28, CAEPR, ANU E Press, ANU, Canberra.

Plumptre, T. and Graham, J. 1999. Governance and Good Governance: International and Aboriginal Perspectives, Institute On Governance, Canada.

Sanders, W. 2003. 'Participation and representation in the 2002 ATSIC elections', CAEPR Discussion Paper No. 252, CAEPR, ANU, Canberra.

2004. 'Thinking about Indigenous community governance', CAEPR Discussion Paper No. 262, CAEPR, ANU, Canberra.

Scott, J. 1988. Seeing Like a State-How Certain Schemes to Improve the Human Condition Have Failed, Yale University Press, New Haven.

Smith, D. E. 1992. 'The cultural appropriateness of existing survey questions and concepts', in J. C. Altman (ed.), A National Survey of Indigenous Australians: Options and Implications, CAEPR Research Monograph No. 3, CAEPR, ANU, Canberra.

-1995. 'Representative politics and the new wave of native title organisations', in J. Finlayson and D. E. Smith (eds), Native Title: Emerging Issues for Research, Policy and Practice, CAEPR Research Monograph No. 10, CAEPR, ANU, Canberra. 
1996. 'From cultural diversity to regionalism: The political culture of difference in ATSIC', in P. Sullivan (ed.), Shooting the Banker: Essays on ATSIC and Self determination, North Australia Research Unit, ANU, Darwin.

2007. 'Networked governance: Issues of process, policy and power in a West Arnhem Land regional initiative', Ngiya: Talk the Law, Governance in Indigenous Communities, 1: 24-52.

Spiro, R. J. and Jehng, J. 1990. 'Cognitive flexibility and hypertext: Theory and technology for the non-linear and multidimensional traversal of complex subject matter', in D. Nix and R. Spiro (eds), Cognition, Education, and Multimedia, Erlbaum Press, Hillsdale, New Jersey.

Strauss, C. and Quinn, N. 1997. A Cognitive Theory of Cultural Meaning, Cambridge University Press, Cambridge.

Sutton, P. 1995. 'Atomism versus collectivism: The problem of group definition in native title cases', in J. Fingleton and J. Finlayson (eds), Anthropology in the Native Title Era, Proceedings of a workshop conducted by the Australian Anthropology Society and the Native Title Research Unit of AIATSIS, 14-15 February, Canberra.

Tapsell, T. 2003. 'Learning from local government reform: The lessons from other Australian jurisdictions', Unpublished paper presented to the Building Effective Indigenous Governance Conference, 4-7 November, Jabiru, NT, available at $<$ http://www.nt.gov.au/cdsca/indigenous_ conference/web/html/papers.html $>$ [accessed 15 May 2008].

Tylor, E. 1894. 'On Tasmanians as representatives of Palaeolithic man', The Journal of the Anthropological Institute of Great Britain and Ireland, 23: $141-52$.

Vanstone, A. The Hon. 2005. 'Beyond conspicuous compassion: Indigenous Australians deserve more than good intentions', Address as Minister for Immigration and Multicultural and Indigenous Affairs to the Australia and New Zealand School of Government, 7 December, ANU, Canberra, available at $<$ http://epress.anu.edu.au/anzsog/policy/mobile_devices/ ch03.html $>$ [accessed 15 May 2008]. 